\title{
Construção de territórios geríveis : (in)definição do lugar do crime contra pessoas na internet
}

\section{Mariana Cintra Rabelo}

\section{(2) OpenEdition \\ 1 Journals}

Edição electrónica

URL: http://journals.openedition.org/aa/1354

DOI: 10.4000/aa.1354

ISSN: 2357-738X

Editora

Programa de Pós-Graduação em Antropologia Social (UnB)

\section{Edição impressa}

Data de publição: 1 julho 2015

Paginação: 107-131

ISSN: 0102-4302

\section{Refêrencia eletrónica}

Mariana Cintra Rabelo, «Construção de territórios geríveis : (in)definição do lugar do crime contra pessoas na internet», Anuário Antropológico [Online], v.40 n. 1 | 2015, posto online no dia 01 junho 2018, consultado o 28 abril 2021. URL: http://journals.openedition.org/aa/1354 ; DOI: https://doi.org/ 10.4000/aa. 1354

\section{(c) (i) $९$}

Anuário Antropológico is licensed under a Creative Commons Atribuição-Uso Não-Comercial-Proibição de realização de Obras Derivadas 4.0 International. 


\title{
Construção de territórios geríveis: (in)definiçáo do lugar do crime contra pessoas na internet
}

\author{
Mariana Cintra Rabelo \\ Pesquisadora independente
}

Em que aspecto uma ação através da internet pode ser territorializada? O que (des)caracteriza a internet como um território mundial? As açôes e interações estabelecidas na internet, aquilo que se vive, se expressa e se recebe por meio dela, têm obrigatoriamente um caráter transnacional?

O objetivo deste artigo é analisar retóricas que orientam processos de (in) definição de competência judicial para julgamento de crimes contra pessoas por meio da internet, tendo como questão central a produção de uma imaginaçáo territorial. A discussão embasa-se em documentos de acórdãos do Tribunal Regional Federal (TRF), Superior Tribunal de Justiça (STJ) e Supremo Tribunal Federal (STF) julgados em 2003, 2004, 2006 e 2008. Os julgamentos envolvem conflitos de competência judicial em casos de crimes de racismo e pornografia infantil propiciados pelo uso da internet, sendo matérias previstas em acordos internacionais ratificados pelo Brasil..$^{1} \mathrm{O}$ material é privilegiado para interrogar sobre imagens territoriais produzidas em processos de legitimação de atuação jurídico-penal. Os acórdáos lidam com três fatos:

a) um rapaz brasileiro, em sua casa no Brasil, comumente faz download de pornografia em seu computador através de uma rede de compartilhamento P2P (peer-to-peer). Parte desse material foi identificado como pornografia infantil durante investigaçóes policiais e, ainda, esse mesmo conteúdo foi detectado em um site alemão (Brasil, 2004);

b) em Aparecida de Goiás, um casal formado por um homem e uma mulher fotografou e filmou crianças e adolescentes em contexto pornográfico. Depois, depositou tais materiais na internet (Brasil, 2003, 2006);

c) um grupo de pessoas de diferentes cidades e estados brasileiros (é sabido, Paraná e Minas Gerais) posta conteúdos discursivos, em português, de caráter ofensivo e discriminatório que incitam preconceito racial em páginas da internet (Brasil, 2008). 
No que concerne ao primeiro caso, havia uma presunção nos processos de que o trânsito de imagens havia passado por servidores cadastrados além das fronteiras nacionais. No entanto, é importante ressaltar que isso não gera necessariamente a conclusão de que as imagens passaram por pessoas situadas em território estrangeiro. Em relação ao segundo caso, não havia uma suposiçáo, a priori, de açôes em outras localidades que náo a cidade mencionada, ou seja, o único local diretamente presumido era Aparecida (GO), que envolve as interaçóes relatadas e que corresponde ao local de uso do computador e internet. E, acerca do terceiro relato, desde o primeiro acionamento da justiça federal (para pedido de quebra de sigilo dos dados dos suspeitos), havia um entendimento de que a circulação dos discursos incitadores estava articulada em diferentes estados brasileiros.

Os acórdãos foram construídos sobre o seguinte conflito: em qual território jurídico aconteceu a ação ilícita e seu resultado? A partir da produção interpretativa que daí se desdobra, é pertinente perguntar de que forma e quando interações numa pequena cidade ou açóes individuais, estabelecidas mediante a internet, poderiam ser enquadradas como condutas de proporçóes "internacionais" ou locais.

As presentes discussões foram suscitadas por relatos etnográficos durante pesquisa que realizei no Grupo Especial de Combate aos Crimes de Ódio e Pornografia Infantil na Internet (GECOP), do Departamento de Polícia Federal (DPF), em 2012. Meus interlocutores e os documentos analisados apontavam para uma tensão entre interpretaçôes que conduzem o trabalho policial e aquelas determinadas pela autoridade judicial diante de um contexto de poucas previsóes jurídicas e legislativas, o de crimes contra pessoas cometidos através da internet. ${ }^{2}$

As primeiras investigaçóes de pornografia infantil na internet, realizadas pela Divisão de Direitos Humanos do DPF, datam de pouco antes dos anos 2000. Durante uma década aproximadamente, pairava certa insegurança acerca da continuidade jurídica da persecução iniciada, visto que juízes e juízas federais declinavam competência para instâncias estaduais e/ou exigiam provas inalcançáveis da repercussão internacional e das condutas investigadas. ${ }^{3}$ Foi-me relatado que, no começo dos anos 2010, essa atuação persecutória tornou-se menos instável, apesar de haver um entendimento nativo de que juízes ainda não estão inteirados em sua totalidade sobre a matéria de investigaçóes na internet e sobre jurisprudências acerca de definiçôes de competência judicial. A mudança é creditada a julgamentos ocorridos nos anos 2000 que corroboraram um entendimento mais coordenado entre juízes e juízas criminais federais e estaduais sobre qual instância deve processar e julgar tais casos, com referência 
especial ao acórdão do STF de 2006, o HC 86289-6 (Brasil, 2006), a ser discutido neste artigo.

A partir da pesquisa no GECOP, pude atentar-me para a construção de uma imaginação territorial e internacional das experiências de uso da internet como interpretação em negociação e disputa. A territorialização das condutas adotadas no uso da internet foi um fator central para análise das atividades desenvolvidas no GECOP e de seu histórico institucional. ${ }^{4}$ Os conflitos de (in)definição territorial revelam mais do que uma significação para os rumos jurídico-penais de um caso. Evidenciam: (a) processos de transformação de noções espaçotemporais, nos sentidos de Anderson (2008), em que relaçóes sociais são locadas a territórios sociais e imaginadas como uma experiência de tais territórios; e (b) a construção de territórios em objetos e ferramentas de gestão, com base nas concepções de Souza Lima (1995, 2002a, 2002b) acerca da imbricação entre conhecimento e gestão política na compreensão de mecanismos de controle sobre territórios. ${ }^{5}$

Esses são os feixes teóricos centrais para a presente análise. Parto, portanto, do pressuposto de que disputas e enquadramentos de interaçóes em termos de extensôes territoriais podem ser analisados como dispositivos de governo, seguindo uma contribuição metodológica foucaultiana para compreender como se atualizam ideias e experiências territoriais sobre sociabilidades virtuais (Foucault, 2002, 2008a, 2008b).

\section{O lugar dos fatos na sensibilidade jurídica}

O material de discussão é fruto de pesquisas eletrônicas sobre acórdãos de conflito de competência judicial para julgamento de práticas da internet previstas como ofensas a direitos humanos. ${ }^{6}$ As interpretações de juízes e juízas, ministros e ministras acerca da localização dos fatos ilícitos são foco das discussôes. Portanto, faz-se necessário apresentar algumas questóes jurídicas e legais que embasam as decisóes das magistradas e dos magistrados.

A localização de uma conduta sob lentes jurídicas é elemento a ser escrutinado observando-se a atualização da "sensibilidade jurídica" 7 que o produz. Portanto, náo deve ser interpretada como constatação factual nem com foco "na capacidade isolada de indivíduos", mas sobre as perspectivas locais, reconhecendo-se o "poder imaginativo, construtivo ou interpretativo" (Geertz, 1997:324) do direito e do sistema jurídico em questão.

Para que o direito penal brasileiro seja aplicável, é requisito identificar a ocorrência da conduta delituosa e, para isso, é imprescindível definir o lugar dos fatos (ação e resultado). ${ }^{8}$ A localização de uma ação ilícita consiste em definir onde, de que forma, por quais meios e em que momento um indivíduo 
agiu corporalmente, com vontade, perseguindo determinada finalidade que posteriormente motivou a ação penal.

A definição jurídica do lugar dos fatos ilícitos é construída pelas ferramentas legais e cognitivas do direito penal, que, por sua vez, limita a si mesmo por princípios que condicionam a abrangência da soberania do Estado brasileiro sobre o "território nacional" (Jesus, 2009). ${ }^{9}$ O direito penal é, assim, um sistema interpretativo que enquadra as açóes humanas nos termos de seus efeitos jurídicos e, ainda, preconcebe uma relação íntima e normativa de pertencimento e comprometimento entre os indivíduos, suas açóes e o território nacional.

O primeiro acórdão que analiso foi julgado pelo TRF de São Paulo em 2004 (Brasil, 2004). Fora detectado pela Polícia Federal que o protocolo de acesso à internet (IP) de um cidadão brasileiro estava associado, mediante acesso direto, a um site alemão que continha material de pornografia infantil. Assim, por meio de investigaçóes policiais, essa pessoa se tornava suspeita de divulgação de pornografia infantil na internet. ${ }^{10}$ Para identificar o suspeito e localizar sua residência, foi movido um pedido de quebra de sigilo, à justiça federal, dos dados cadastrais do usuário na provedora do acesso.

Ao dar parte do pedido, a juíza federal da $4^{\text {a }}$ Vara Criminal de São Paulo entendeu que não era de sua competência o julgamento da matéria e, sim, da justiça estadual. A matéria, então, foi apresentada ao TRF pelo Ministério Público, solicitando o reconhecimento de competência da justiça federal para processar e julgar os fatos. A partir do decline da juíza, houve uma quebra no fluxo de aplicação jurídico-penal. ${ }^{11} \mathrm{E}$ iniciou-se um processo de negociação acerca do enquadramento normativo do caso com a finalidade de produzir uma compreensão legitimada sobre a aplicabilidade jurídica. Esse enquadramento foi dado pelo Recurso Criminal em Sentido Estrito (RCCR) 48.936-SP, cuja ementa diz:

I - Extraterritorialidade condicionada da Lei Penal Brasileira (art. 7o, II, a, do $\mathrm{CP}$ ) concernente ao Princípio da Justiça Universal ou Cosmopolita. Aplicação concomitante da Teoria da Ubiqüidade em relação ao lugar do crime eis que delito de execução transnacional (art. $6^{\circ}$ do $\mathrm{CP}$ ).

II - A execução e consumação ocorreu através da Internet, englobando, ao menos, dois países: Brasil e Alemanha. Fato que, aliado à existência de acordo internacional tratando do tema, conduz à competência da Justiça Federal para processamento e julgamento do feito. 
III - Crime instrumentalmente conexo à rede telemática, considerando-se a utilização da rede mundial de computadores para consecução da prática criminosa (delito informático impróprio).

$[\ldots]$

$\mathrm{V}$ - A previsão de combate internacional à pornografia de menores, prevista em decreto, encontra, em seara legislativa interna, consonância e arrimo no delito previsto no art. 241 do ECA, antes e depois da redação dada pela lei 10.764/03 (Brasil, 2004:ementa).

O TRF deferiu por unanimidade o pedido do Ministério Público de conferir competência à justiça federal, um resultado embasado por dois eixos. Primeiro, a compreensão sobre o lugar dos fatos com ênfase na noção de que a ação teve repercussões em diferentes territórios nacionais. Segundo, a aplicação do princípio da extraterritorialidade, visto que, além de ter sido praticado por brasileiro e tocado território estrangeiro, o suposto crime está previsto em convenção de proteção a direitos humanos ratificada pelo Brasil.

No acórdão, a internet aparece como meio de comunicação que permitiu que determinada ação tivesse efeitos em diferentes territórios. Foi dessa forma que o lugar dos fatos pôde ser ubiquamente reconhecido no Brasil - como lugar da ação corpórea de "apresentar, produzir, vender, fornecer, divulgar ou publicar" 12 (BRASIL, 1990a) conteúdo de pornografia infantil e do cadastro do IP de acesso - e na Alemanha, como lugar do resultado e território de cadastramento do site onde estavam as imagens.

$\mathrm{Na}$ interpretação da juíza da vara criminal, não havia, em princípio, nenhum elemento no processo que fixasse a competência da justiça federal. Contudo, os autos percorriam um contexto em que promotores e promotoras e policiais federais produziam conhecimentos diversos acerca de crimes propiciados pelo uso da internet. A "transnacionalidade" é o enquadramento produzido nesse acórdão do TRF e, nele, a internet aparece como ferramenta que possibilitou a articulação territorial. Essa imaginaçáo acionada pela experiência do uso da internet é traduzida pela categoria "englobar", que revela a compreensão final de um caráter "transnacional" do feito ilícito, aparecendo a internet como instrumento desse efeito. Contudo, é importante frisar que a territorialidade do delito não é deslocada para a experiência da internet; esta é apenas chave para reconhecer territórios juridicamente geríveis. A internet é entendida como meio de comunicação que possibilita a repercussão de açôes sobre territórios distintos. 
Como foi apresentado, "o que aconteceu” está em questão e "onde" é o elemento que precisa ser adequado às concepçôes da sensibilidade jurídica. Diferentes interpretaçóes sobre o uso da internet estão sendo lançadas neste contexto, e os processos de conflito de competência judicial são um empreendimento de negociação dessas perspectivas e de sua aplicação legitimada.

\section{Traduçóes jurídicas e imaginação territorial}

Os julgamentos e a produção de decisôes em instâncias superiores possuem caráter ritual, trazendo à tona as chaves interpretativas (Goffman, 1974) que permitem que certo conflito seja objeto de redefinição em um nível de autoridade cada vez menos passível de ser desacreditado ou renegociado. Sendo a localizaçáo do crime o objeto de negociação e disputa, nos termos de Goffman, há lâminas, referentes à interpretação do objeto de análise social, que vulnerabilizam a própria análise e não permitem, em primeiro momento, a sua definição compartilhada. ${ }^{13}$ Ou seja, elas oferecem limites à aplicação do enquadramento jurídico-penal quando da definição do lugar do crime.

Quando diferentes instâncias judiciais são acessadas e questionadas, esse ritual empreende a restauração das possibilidades de tradução pacífica entre o mundo dos fatos, o ordenamento jurídico e a organização prática judicial, uma vez que encontra no universo das leis a interpretação que autoriza a atuaçáo judicial para a gestão jurídico-penal de uma situação.

Os julgamentos das matérias de conflito de competência operam sobre os ramos hierárquicos das relaçôes entre tribunais, juízas e juízes, promotoras e promotores, e polícias, definindo limites e legitimidades de suas atuaçôes segundo significaçôes territoriais: "quem" exerce autoridade e "onde", dentro de uma arena de relaçôes bem marcadas de poder (TRF, STJ, STF). Quando processa e decide, a instância de julgamento, centrada no poder relativo de seus ministros e ministras e seus desembargadores e desembargadoras, atualiza uma propriedade em exaurir conflitos baseados na confusão de definição situacional.

O segundo e terceiro processos que discutirei foram conduzidos pelo STJ (BRASIL, 2003) e pelo STF (BRASIL, 2006), respectivamente. São julgamentos de pedidos de habeas corpus impetrados por réu condenado a três anos e quatro meses de reclusão por ter, com outra pessoa, fotografado, filmado e postado na internet imagens de menores de idade em contexto pornográfico. ${ }^{14} \mathrm{~A}$ partir da condenação, o réu deu entrada a pedidos de habeas corpus em que, a cada negativa, era acionada a instância judicial superior.

A condenação veio da 5a Vara da Seção Judiciária Federal do Estado de Goiás: os réus (o homem e uma mulher) foram julgados por corrupção de menores ${ }^{15}$ e por Anuário Antropológico/2014, Brasília, UnB, 2015, v. 40, n. 1: 107-131 
"fotografar" pornografia infantil e "publicar" na internet. O réu recorreu com um pedido de habeas corpus, alegando incompetência da justiça federal para processar o caso, pois o crime não havia se consumado fora do país. O pedido foi, assim, apreciado pela $4^{\mathrm{a}}$ Turma do TRF da $1^{\mathrm{a}}$ Regiáo, que ratificou a competência da justiça federal. A parte, novamente, recorreu e o pedido passou a ser julgado pela $6^{a}$ Turma do STJ. Esse tribunal também firmou a competência da justiça federal. A parte recorreu outra vez e, por fim, o caso tornou-se matéria de apreciação do STF. ${ }^{16}$

Começarei pela discussão do acórdão do STJ (Brasil, 2003). Antes, é importante dizer que, além de a definiçáo do lugar do crime ser questionada no recurso, está em questão o tempo do fato ilícito. De acordo com o direito penal, o momento do crime é determinado pelo momento da ação (ou omissáo), e não pelo momento do resultado (Brasil, 1940:art. 4, caput). Dessa forma, alega o impetrante:

"a conduta foi praticada em Aparecida de Goiás" e, ainda que a internet "projete o fato para o exterior (o que efetivamente acontece), há separação no tempo e no espaço, entre a ação e o resultado, ainda que por diminuta fração de tempo" (Brasil, 2003, citaçôes em voto:20).

O primeiro juiz a votar é o relator do processo, ministro Paulo Medina, que declara a incompetência da justiça federal e a competência da justiça comum para julgar o caso. Em seu voto, argumenta que o tempo da ação de fotografar é diferenciado e anterior ao momento de publicação, e que o crime previsto no artigo 241 do ECA já estava consumado pelo ato de "fotografar".

O segundo a votar é o ministro Carlos Fontes de Alencar, que entende que a competência é da justiça federal. Em seu voto, assinala que a questão não se encontra no acesso, que pode ou não ter ocorrido no estrangeiro, nem na divisáo sequencial dos atos de "fotografar" e "publicar", como entendeu seu colega anterior, mas na intenção dos atos:

Senhor Presidente, de acordo com a leitura da denúncia, as fotografias e a filmagem foram atos praticados para posterior publicação na Internet. [...]

O crime não ocorreu no estrangeiro porque ninguém acessou o endereço dado. Tal circunstância é irrelevante para afastar a competência da Justiça Federal. Com meus louvores ao eminente Advogado e Professor, entro em colisão de entendimento com o eminente Ministro-Relator e denego a ordem de habeascorpus (Brasil, 2003, voto:7). 
Já o terceiro voto não consta de apresentação, apenas concorda com o anterior e denega o habeas corpus. O quarto e último voto, do ministro Paulo Gallotti, também coaduna os dois anteriores e enfatiza que a "manifesta intenção de divulgação no exterior" (ou seja, de colocar as imagens na internet) é a prova para determinar a aplicação da extraterritorialidade. Assim, com três votos a um, o pedido de habeas corpus é indeferido, e a competência da justiça federal é estabelecida pelo STJ.

Destaco, primeiramente, a relação entre tempo e local do crime — os ministros foram provocados a responder sobre a realidade do fato ilícito. Como é possível perceber na diferença de interpretação entre o relator e os demais, a imaginaçáo temporal está ligada à imaginação territorial. Se os núcleos do tipo penal, "fotografar ou publicar", forem dissociados na concepção "do que aconteceu" (como votou o ministro Paulo Medina), a ação ilícita e seu resultado são localizados em Aparecida de Goiás, na casa onde o casal fez as fotos e usou o computador. Apenas o ato de "publicar" as imagens na internet, como consumação do crime, teria o poder de acionar outra imaginação territorial. Algumas interpretaçóes estấo postas:

a) que os atos ilícitos deveriam ter sido "consumados" coordenadamente, compondo o mesmo dano jurídico de expor menores em contextos pornográficos. Dessa, desdobram-se duas compreensões: uma, de que fotografar e publicar foram ações realizadas no Brasil, atraindo competência da justiça comum, e que, ainda que o material fosse acessado fora de território nacional, esse acesso não significaria o resultado do crime, mas apenas seu exaurimento (esse argumento irá embasar a defesa do réu no julgamento do STF); a outra, de que as açóes propiciaram uma repercussão internacional, atraindo competência da justiça federal (essa interpretação depende exclusivamente de traduções específicas sobre o uso da internet, como nos três votos que corroboraram a decisão final). $\mathrm{Ou}$

b) que a publicação se deu em momento separado, ou seja, a ação ilícita em julgo é a de fotografar, atraindo competência da justiça comum (esse é o entendimento do relator e da defesa do réu).

A tradução final produzida pelo acórdão do STJ foi de que o fato teve, ou deveria ter tido, resultados no exterior (Brasil, 1988:art. 109, V). Publicar e fotografar, necessariamente separados num tempo cronológico, são açóes ligadas num tempo jurídico pelo aspecto volitivo da ação ilícita. A "intenção" permite 
que a imagem de açôes localmente circundadas seja transformada na ideia de que os fatos poderiam ter tido efeitos no estrangeiro.

O uso da internet tem um papel interpretativo central nesse julgamento por meio da ação típica de "publicar" com a ideia de efeitos possíveis em territórios estrangeiros. Por várias vezes nos votos, a internet foi referida como "rede mundial de computadores", categoria que aciona certa imaginação. No voto do ministro Fontes de Alencar, a inserção de dados na internet define a potencialidade transnacional do crime, de tal forma que não seria necessário o acesso ao conteúdo em locais estrangeiros.

Tanto na decisão do STJ como no primeiro acórdão analisado (Brasil, 2004), o uso da internet é nuance que vulnerabiliza a localização jurídica. Mas há alguns aspectos a serem considerados sobre como foram construídos entendimentos em cada caso. No julgamento do TRF, ela apareceu como uma rede de comunicaçóes que possibilitou um efeito transnacional. Já no julgamento do STJ (Brasil, 2003), a imagem de uma potencialidade transnacional parece deslocar a compreensão situacional para uma concepção de que a internet modifica necessariamente o enquadramento territorial das açóes por ela perpetradas (resguardadas diferenças de entendimento entre magistrados).

Pois bem, após a recusa do pedido de habeas corpus pelo STJ, o réu recorre ao STF. Nesse fórum, novas informaçôes compóem o processo. Há a afirmação de que houve acesso na Bélgica e na França aos conteúdos pornográficos postados. E a defesa, agora, lança mão do argumento de que a consumação do crime se deu no Brasil e de que o acesso às imagens no estrangeiro corresponde apenas ao exaurimento do crime.

No STF (Brasil, 2006), os votos expressam uma maior diversidade de compreensóes dos ministros do que no STJ, e é importante remontar tais argumentos. ${ }^{17}$ Iniciando, apenas o ministro Marco Aurélio assenta competência da justiça comum:

Não tenho a menor dúvida de que o crime se consumou no Brasil. A partir dessa consumação - e a publicação se fez na inserção no computador que aqui se encontrava -, a partir dessa publicação é que se procedeu a diversas remessas, possivelmente, até mesmo, para endereços da internet situados no País.

Não tenho como confundir o que se contém no mencionado inciso $\mathrm{V}$ a ponto de proceder à leitura desse preceito como a revelar o englobamento, o alcance de apanhar não a prática do crime como está no dispositivo, mas as repercussóes diversas, múltiplas, que não se referem à configuração do tipo ocorridas no estrangeiro (Brasil, 2006:311). 
Nesse voto, o ministro concorda com o pedido de habeas corpus e afirma que os efeitos possíveis de "englobamento" de territórios nacionais não estão atrelados à concretização da ação ilícita em si. Ele não deixa de considerar que houve repercussóes internacionais após a "publicação" de imagens, mas coaduna o argumento que separa o tempo entre esses efeitos e a ação ilícita que os provocaria. E não há questionamento sobre o que gera ou geraria o uso da internet; os argumentos são relativos à previsibilidade dos crimes em convençóes internacionais e à separação temporal que permite um enquadramento territorial local.

Outros três votos, dos ministros Carlos Brito, Cezar Peluso e Sepúlveda Pertence, assentam competência da justiça federal. Apresento-os em bloco por aproximação dos argumentos:

No caso, penso que o resultado do crime é a própria ocorrência do dano sofrido pelo bem jurídico tutelado. O que se deu com o instantâneo, o desembaraçado acesso de qualquer pessoa às fotos exibidas pela rede mundial de computadores, o momento da consumação do crime, no caso, deu-se exatamente com a disponibilização das fotos para qualquer pessoa. (Brasil, 2006:306. Voto do ministro Carlos Britto).

O tipo era publicar. Com inserção das fotos na rede internacional, deu-se a publicação imediatamente, de modo que os resultados, também, se produziram no exterior desde aí (Brasil, 2006:308. Voto do ministro Cezar Peluso).

Aqui, o crime se consuma com a publicação, que é tornar disponível, acessível, pela rede da internet, determinada mensagem (Brasil, 2006:314. Voto do ministro Sepúlveda Pertence).

A noção de uma potencialidade transnacional da experiência da internet é novamente acionada como chave interpretativa para enquadrar o tempo e a territorialidade do crime. E, também, o uso das categorias "rede mundial" e "rede internacional" retroalimenta a imagem de que diferentes territórios nacionais podem ser tocados. Essa interpretação, é bom lembrar, determinou o resultado do acórdão anterior.

Restam, agora, dois argumentos a serem levantados, o do ministro e relator do processo, Ricardo Lewandowski, e o do ministro Carlos Britto, que realiza uma confirmação de voto ao final do julgamento. $\mathrm{O}$ relator expóe as vulnerabilidades interpretativas que estão em negociação nesse julgamento. Explicita que o uso da internet oferece entraves interpretativos à aplicação do direito penal, com a lei 
vigente na época do crime, principalmente no que diz respeito à compreensão do resultado do crime:

O desenvolvimento da rede mundial de computadores, em ambiente virtual de armazenamento de informaçôes binárias, ultrapassou as possibilidades de previsão do legislador acerca das eventuais decorrências do fenômeno. [...] Tanto que a lei foi posteriormente alterada para adequá-la às circunstâncias da realidade.

O questionamento que aqui se apresenta, no entanto, trata em se saber quando ocorre o resultado do crime do artigo 241 do ECA, na sua redaçáo original, quando praticado através do ambiente virtual (Brasil, 2006:302).

A ênfase recai mais uma vez sobre o tipo referido em lei, "publicar", para a definição de como se deu, o que gerou e que danos causou o crime. Segundo o ministro, o que está em negociação é no que consiste esse "publicar" em "ambiente virtual”.

$\mathrm{Na}$ forma como o relator conduz seus argumentos, três pontos se destacam. Primeiro, a afirmação de que o desenvolvimento da tecnologia da "rede mundial de computadores" traz novas realidades a serem compreendidas pelo ordenamento jurídico-penal. Segundo, a referência à internet como um terreno específico, "ambiente virtual". E, terceiro, a explicação sobre de que terreno se trata, relegando a ele um funcionamento próprio e, assim, transformando a imaginação do espaço-tempo das condutas na internet:

No ambiente virtual há a disponibilização de material eletrônico, o qual somente passa a ser inteligível ao ser humano quando de seu acesso por outro usuário. A sensação de imediatidade da imagem nos leva a crer que tenhamos entrado em outro ambiente, quando, na verdade, solicitamos o envio da informação digital. Acessar, portanto, em ambiente virtual, significa solicitar o envio de informações, e recebê-las. Ao recebermos o sinal transmitido pelo servidor de arquivos, essa informação é então processada e transformada em imagem. A consumação da conduta "publicar", quando em ambiente virtual, na modalidade de disponibilizar imagens, como é o caso que se apresenta, somente ocorre quando a informação binária passa a ser inteligível ao receptor. E isso somente ocorre após o efetivo recebimento das informaçóes eletrônicas pelo solicitador do acesso. Exaure-se o crime no mesmo instante da consumação, sendo dela dependente (Brasil, 2006:302, grifos meus).

Então, para o relator, o ato de "publicar" na internet tem significado próprio. Ela é caracterizada como terreno específico de sociabilidades. A ação de "publicar" só se torna efetiva, ou seja, as imagens só se tornam disponíveis 
para o público quando são recebidas mediante o acesso desse público. Assim, em sua interpretaçáo, o crime se consuma no mesmo momento em que exaure seus efeitos (de expor menores em situação degradante). O esforço argumentativo é de colocar a ação por meio da internet em um quadro compreensível pelo direito, localizando-a em terreno conhecido de sociabilidades que podem ser antecipadas.

Trata-se da produçáo de reconhecimento e conhecimento acerca de trocas e circulação de discursos na internet, de sua engenharia e territorialidade em termos de nação, das ações e da verdade dessas açôes a serem antecipadas. Isso pode ser analisado à luz de um poder de segurança, em que os espaços ganham noçáo de meio como "suporte e elemento de uma ação" (Foucault, 2008a:27). É sobre a ação que se concentram esforços de regularização desse ambiente "multivalente e transformável” (Foucault, 2008a:27). E é uma ação não entendida, a princípio, pelo aspecto de uma vontade individual, mas por uma noção de produção de acontecimentos que geram efeitos sobre a inteligibilidade do meio. ${ }^{18}$

Há duas peculiaridades que quero destacar sobre esse voto. Primeiro, nele há uma compreensão situacional do fato. A extraterritorialidade, aqui, só existe porque houve acesso de terceiros em território estrangeiro: "a competência firmada no caso em concreto deveu-se ao fato de que a consumação do ilícito ocorreu além das fronteiras nacionais, especificamente em território europeu" (Brasil, 2006:304). As açôes devem ser entendidas contextualmente; não se trata de significar a experiência da internet como de uma potencialidade internacional. A imagem acionada aqui é outra.

A segunda toca no ponto central de produção do acórdão do STF: “o avanço da tecnologia não significa permissão de que a conduta humana esteja livre de responsabilização penal” (Brasil, 2006:301). E tal produção vincula e loca uma noção territorial específica à experiência da internet, como a "experiência em ambiente virtual". Há uma tradução da internet à luz das concepçôes normativas como um território gerível.

Por fim, a confirmação de voto do ministro Carlos Brito:

Senhor Presidente, também entendo que, hoje em dia, quem entra na rede mundial de computadores em caso que tais não tem como deixar de iniciar o crime no Brasil e se expor ao risco da consumação fora do Brasil. É imediata. Uma coisa puxa a outra. É da natureza desse tipo de comunicação eletrônica (Brasil, 2006:315).

O magistrado finaliza o processo referindo-se a nuances interpretativas contidas nos votos de seus colegas. Aciona novamente a imagem da potencialidade 
transnacional, dando ênfase aos efeitos das açôes possibilitadas pelo uso da internet; porém, agora, como efeitos necessários de sua "natureza".

O julgamento do STF trouxe à tona empreendimentos de imaginação territorial focada no funcionamento "técnico" e até "natural” da internet. A interpretação concebe as açóes como realizadas na internet e, ainda, como geríveis em seus efeitos, seja sobre o próprio meio, seja sobre a afetação mútua dos indivíduos que nele atuam. ${ }^{19}$ Essa transformação (Goffman, 1974) não corresponde à delimitação de um território nacional ou internacional, mas a tradução realizada tem como fio condutor a compreensão de tais experiências em termos de nação. Um rol de interaçôes passará, então, a ser inteligível sob uma ordem cognitiva de espaçotempo transformada pela sensibilidade jurídica.

\section{Conflitos de competência: (in)definiçóes do lugar do crime}

Por fim, abordo o último acórdáo, o Recurso Criminal em Sentido Estrito julgado no TRF da 1 1a Região (Brasil, 2008). ${ }^{20} \mathrm{~A}$ matéria ocupa-se de incitação à prática de “preconceito de raça, cor, etnia (art. 20, $\$ 2^{\circ}$, da Lei 7.716/89)" em sites da internet.

A juíza federal da $4^{\mathrm{a}}$ Vara da Seção Judiciária de Minas Gerais remeteu à competência da justiça estadual de Belo Horizonte (MG) os autos de um processo instaurado por uma Procuradoria Regional (no Paraná) em que, após a quebra de sigilo telemático dos sites, verificou-se que a maioria dos IPs eram localizados em Minas Gerais. A juíza defendeu que "tanto o resultado quanto a execução do crime [...] ocorreram dentro do território nacional" (Brasil, 2008:1). De acordo com ela,

a simples divulgação do delito pela Internet não atrai, por si só, a competência federal. Faz-se necessária, para a fixação do Juízo Federal, a comprovação da internacionalidade, que se dá com o nexo de causalidade entre ação e o resultado (Brasil, 2008:2).

A necessidade de "comprovação da internacionalidade" revela a dimensão situacional da compreensão da magistrada sobre os fatos. Não havia nada que colocasse o uso da internet como uma imprescindibilidade de risco, alcance, englobamento, repercussão ou experiência internacional. Essa visão da juíza é importante para que eu possa diferenciar pontos levantados até agora, portanto, abro um longo parêntesis.

Como isso que chamei de "compreensão situacional" da magistrada difere dos outros argumentos apresentados e se articula com eles? $\mathrm{Na}$ fala dela, não é negada a possibilidade de que o resultado do crime aconteça em diferentes territórios, 
mas essa possibilidade está ligada a um entendimento da internet como meio de comunicação que, como tal, permite que haja efeitos de determinadas açôes em diversas dimensóes do espaço e do tempo; essa perspectiva também é apresentada no acórdão do TRF (Brasil, 2004).

Já no argumento do ministro Ricardo Lewandowski no julgamento do STF (Brasil, 2006), a "compreensão situacional" aparece de outra forma. O ministro defende que a transnacionalidade não está atrelada necessariamente ao uso da internet. Contudo, a explicação que é acionada sobre a internet e seu uso realiza outro tipo de tradução, que não tem como ênfase um meio de comunicação capaz de "englobar" diferentes pontos de ação. O conhecimento desse meio de comunicação como meio de sociabilidades é a transformação central manejada em seu voto. A “compreensão situacional” é possível e realizável sobre um contexto acerca do qual há conhecimento e antecipação jurídica.

É sob a lente de conhecimento do funcionamento da internet que o julgamento do STF encaixa, na definição dos fatos, os aspectos temporais. Ação, interação e seus respectivos efeitos são reconhecíveis nesse meio: por exemplo, o exaurimento do crime (danos outros), através da internet, dá-se necessariamente com a consumação da ação de "publicar".

Ainda, para concluir sobre as vulnerabilidades interpretativas e as traduções produzidas em cada caso, no primeiro acórdão analisado (Brasil, 2004), a internet não está sendo imaginada como um território. No segundo julgamento (Brasil, 2003), também não, mas há nuances mais complexas. No STJ, uma série de possibilidades de interação virtual é transformada em experiência específica, reconhecida como contendo uma potencialidade própria de ação e efeitos sobre territórios, a internacionalidade. Essa experiência pode ser fragmentada em pontos de ação e ancorada em áreas fixas e, então, ser interpretada em termos de território nacional, apesar de não poder ser automaticamente enquadrada no simbolismo de territórios político-geográficos, mesmo sendo produtora de confusão dessas fronteiras.

Dito assim, acredito ter exposto mais detalhadamente as diferenças e aproximaçóes das chaves acionadas nos votos e dos enquadramentos firmados nos acórdãos; portanto, fecho o parêntesis. Volto, agora, ao julgamento de crimes de racismo pelo TRF (Brasil, 2008). Após o decline de competência, o Ministério Público Federal entrou com recurso no TRF da $1^{\text {a }}$ Região para solicitar a determinação da competência da justiça federal para julgar o caso, o que foi deferido pelo TRF.

Esse acórdão reserva alguns pontos interessantes. Ele é, praticamente, composto de citaçóes de decisóes judiciais acerca de conflitos de competência em Anuário Antropológico/2014, Brasília, UnB, 2015, v. 40, n. 1: 107-131 
casos de pornografia infantil na internet, entre os quais estão argumentos do STJ (Brasil, 2003) e do STF (Brasil, 2004). Cabe ressaltar a força de acionamento da decisão do STF como recurso de autoridade, visto sua posição máxima de poder de definição "do que está acontecendo" à luz das sensibilidades jurídicas. Como adiantou Geertz (1997:262), os acórdãos são "a marca simbólica que dá autenticidade à retórica jurídica".

Embasado na citaçáo de argumentos já analisados aqui e de distintos acórdãos, o juiz Tourinho Neto, do TRF da 1a Região, define seu voto e o acórdão. Dessa forma, a veiculação de discursos racistas por meio da internet protagonizados por brasileiros, aqui residentes, com acesso protocolado no Brasil e em ação primeira em território brasileiro, foi enquadrada como de potencial repercussão internacional. O conflito foi contornado pelo conhecimento e pela autoridade de definição, outrora proferidos por outras cortes. Em uma das citações, está outro julgamento do STJ de 2007:

todavia, no caso em apreço, urge enfrentar questáo espinhosa: onde ocorre a consumaçáo em se tratando de crime cometido por meio da rede mundial de computadores?

$[\ldots]$

É certo, ainda, que tais informaçôes são acessíveis em qualquer parte do mundo em que se disponha de um terminal de computador conectado à referida rede. E é justamente esta diversidade de locais em que a informação pode ser acessada que revela o engessamento das normas de direito processual penal frente às inovaçóes tecnológicas perpetradas pelo homem, ante a dificuldade de identificação do local da consumação do ilícito, como exige a regra geral contida no art. 70 do Código de Processo Penal, para fixação da competência (Brasil, 2008:4).

Assim, há um limite experimentado e promulgado ao enquadramento do direito penal sobre açôes através da internet. E diferentes esforços imaginativos, nos termos de Anderson (2008), são acionados para realizar uma transformação dessas barreiras que se impóem justamente sobre a compreensão espaçotemporal dos fatos a serem definidos e geridos.

Nesses julgamentos, toda a inteligibilidade em jogo busca reenquadrar uma representação normativa centrada na definiçâao de territorialidades, seja pela reformulação de noçôes escalares em termos de territorialidades nacionais, seja pela retórica do simulacro $^{21}$, seja pela construção de uma "comunidade 
imaginada" como "mundial". Mas, necessariamente, essa tradução produz novas "sensibilidades aos espaços que o mundo contém" (Harvey, 1996:265).

A forma e os rumos de sedimentação de tais produçôes imaginativas na aplicação jurídico-penal são matérias muito profícuas para novas pesquisas. Os documentos abordados inserem-se em um contexto em que conhecimentos diversificados são produzidos na gestão das condutas realizadas através da internet. Tais dissidências vão sendo "contornadas" (Geertz, 1997:331) e apropriadas dentro da própria estrutura hierárquica e territorializada do sistema jurídico-penal: os níveis de autoridade em "descrever o mundo" vão sendo acionados, e essas descriçóes são negociadas e ratificadas.

\section{Outras perspectivas analíticas}

A proposta deste artigo foi de adentrar a centralidade que a definição de territórios assume no tratamento jurídico-penal de crimes praticados através da internet. Uma vez que a definição espaçotemporal do crime é elemento necessário à atuação da organização jurídico-penal, a localização revelou-se empreendimento interpretativo imprescindível acerca da verdade das condutas ilícitas. E, nesse sentido, também da própria legitimidade de gestão persecutória dessas condutas.

O objeto central de análise foi a maneira como o lugar do crime é negociado e estabelecido nos votos, relatórios e acórdãos finais. As interaçôes e trocas virtuais ofereceram desafios à gestão jurídico-penal; procurei discutir esses limites de interpretação e, principalmente, como tais fissuras são resolvidas por uma sensibilidade jurídica ancorada no reconhecimento de açôes territorializadas.

Não havia prescriçôes normativas que delimitassem as fronteiras e extensôes dos mecanismos de segurança sobre a internet à época dos casos analisados. ${ }^{22}$ Contudo, se aos espaços físico-geográficos são atribuídas as condutas humanas significativas para o direito penal, se é sobre essa seara que o ordenamento jurídico se exerce, se organiza e caracteriza suas possibilidades de ação, é nesses termos que a internet será escrutinada e traduzida.

As reformulações interpretativas de magistrados e magistradas sobre o lugar dos fatos e da competência judicial revelam que o enquadramento do ambiente virtual estava e está em contexto de transformação e de imaginação territorial.

O poder de produzir legitimação jurídica está depositado justamente na capacidade de realizar essa tradução. Declinar competência judicial, nos casos em questão, é redefinir os termos da tradução (keying), é acionar a chave interpretativa (key) que permite o reenquadramento da situação ("o que está acontecendo”), de forma a dirimir a tensão de como se deve aplicar o direito penal objetivo. 
Acredito que as discussóes levantadas neste artigo propiciam outras entradas analíticas e etnográficas, principalmente, sobre processos de construção de imaginaçóes territoriais de pertença e experiência internacional. Os acórdãos diziam respeito também a novas imagens de poder estatal em processos de legitimaçáo. Não foi foco deste artigo, mas a forma como as retóricas de previsão em tratados internacionais estáo presentes nos votos aciona pertenças e legitimidades. Nesse sentido, o desenvolvimento de dispositivos de governo em torno de uma atuação imaginada como transnacional também é emblemático para os enquadramentos produzidos.

A ideia de uma polícia articulada por uma agenda governamental mundial era central para as atribuiçóes de meus interlocutores no GECOP. ${ }^{23}$ Essa ideia perfaz os diversos entendimentos das polícias, dos promotores e das promotoras e dos desembargadores e das desembargadoras que solicitavam o reconhecimento de competência da justiça federal para processar e julgar crimes contra pessoas perpetrados pela internet nos anos 2000. É importante que se estude esse contexto de construção de um respaldo operacional cada vez maior sobre processos imaginativos de espaços "mundiais", "globais", "internacionais".

Tais processosestão em correspondênciacomuma constante "reterritorialização" (Gupta \& Ferguson, 2000) que marca as análises antropológicas do mundo pós-moderno no final dos anos 1880 e, principalmente, nos anos 1990. Sáo territorialidades cujos significados náo se esgotam e em que identidades, sentimentos e definiçóes de instâncias "locais", "regionais", "nacionais" são disputados em complexos campos de poder. Esses processos são, em sua essência, "escalares". ${ }^{24}$ A operacionalidade de uma "governamentalidade transnacional" e um território imaginado como "global" não substitui o sistema de Estados nacionais, pelo contrário, reforça a legitimação da autoridade estatal sobre o "local” (Ferguson \& Gupta, 2002:981).

É importante perguntar sobre o engendramento de uma "governamentalidade transnacional” e os mecanismos que aí se executam. E, ainda, perseguir as possibilidades e limites em que o artefato da nação, como sentimento e autoconsciência (Anderson, 2008), pode ser transportado para um contexto de imaginação de novas territorialidades. Também considero profícua para futuros artigos a centralidade do conhecimento e reconhecimento de territórios na definição de populaçóes e, a partir de entáo, o delineamento de açóes de gestão sobre elas em seus movimentos. Assim como trabalhei em Rabelo (2013), é rentável abordar uma tradução jurídica de territórios como empreendimento de reconhecimento de açóes de uma alteridade. 
Sendo assim, é imprescindível resgatar os conceitos de tutela e conquista de Souza Lima (1995), especialmente em discussões sobre menoridade e produção de uma alteridade enquadrada como carente de administração. E resgatar, também, os conceitos de governamentalidade (Foucault, 2002) e seus mecanismos ligados à segurança e à atualização ininterrupta de reconhecimentos acerca do que é do Estado, do que é nacional, da demarcaçáo de um território a ser conquistado e da legitimação de atuaçóes sobre as populaçôes em movimento.

Concluindo, a produção de noções territoriais locadas à experiência da internet atualiza um poder de gestáo sobre as causas e os efeitos das condutas humanas aí perpetradas. Os julgamentos estudados protagonizam um empreendimento de gestão sobre açóes e seus efeitos em espaços e sociabilidades conhecidos, remontando a uma noção de meio e tendo a imaginação jurídica de territórios nacionais como eixo producente.

O manuseio de jurisprudências, no trabalho persecutório policial no GECOP, trouxe à tona um ponto sensível da relaçáo entre a potência de hibridismos da virtualidade e os dispositivos jurídicos penais: a construção de um consenso sobre a internet como território gerível é um processo recente e náo absoluto. Os acórdãos aqui analisados fazem parte de um contexto em que as interaçóes na internet estão sendo juridicamente entendidas como sociabilidades de "repercussão internacional", ainda que em questionamento e divergência.

Recebido em 29/12/2013.

Aprovado em 20/06/2014.

Mariana Cintra é mestra em antropologia social pela Universidade de Brasília, com pesquisa etnográfica sobre Polícia Federal, tutela, menoridade, sexualidade e violência. Atua acadêmica e profissionalmente na área de direitos humanos e enfrentamento à violência contra mulheres e LGBTTTs. Atualmente, é professora de sociologia do quadro efetivo da Secretaria de Estado de Educação do Distrito Federal. Escreveu a dissertação Salvar cordeiros imolados: a gestão do combate à pornografia infantil na internet e a proteçāo de crianças (RABELO, 2013). Contato: mcintrabelo@gmail.com. 


\section{Notas}

1. Convenção Internacional sobre a Eliminação de Todas as Formas de Descriminação Racial, de 1968 (Brasil, 1969), e Convenção sobre os Direitos da Criança, de 1990 (Brasil, 1990a).

2. A dissertação, Salvar cordeiros imolados: a gestão do combate à pornografia infantil na internet e a proteção de crianças (Rabelo, 2013), teve como foco empírico as representaçôes sobre crianças e adolescentes no trabalho da Polícia Federal na apuração de crimes de pornografia infantil na internet, o que propiciou a identificação de procedimentos centrados na definição de territórios de gestão. Foi conclusivo que as práticas etnografadas no GECOP se rearranjam e incidem cotidianamente sobre o delineamento de novos terrenos de intervenção, tais como a circulação de imagens e discursos na internet.

3. De acordo com a Constituição Federal de 1988, é de competência dos juízes e das juízas federais processar e julgar "crimes previstos em tratado ou convençấo internacional, quando, iniciada a execução no País, o resultado tenha ou devesse ter ocorrido no estrangeiro, ou reciprocamente" (Brasil, 1988:art. 109, inciso V).

4. Tais discussões encontram-se no segundo capítulo de minha dissertação, "Localizar e individualizar: construção de territórios geríveis" (Rabelo, 2013). O capítulo aborda a provocação empírica sobre uma (des)naturalização da internet como território transnacional e a construção de legitimidade de gestão persecutória. Com base nesses dois feixes, a discussáo recai sobre processos de transformação e traduçáo de terrenos sociais em noçôes territoriais em termos político-geográficos e jurídico-penais. É importante enfatizar que a oportunidade de escrever este artigo me possibilitou novo estudo dos acórdãos e novas compreensões dos votos dos magistrados e das magistradas e dos resultados dos julgamentos. Portanto, algumas questóes que levanto se diferenciam das conclusões elaboradas na dissertação.

5. A partir dos estudos sobre as práticas administrativas indigenistas no Brasil, o autor aponta a incidência de novos e velhos saberes que marcam diferenças sociais e significam os espaços sob a forma de uma administração cotidiana de sujeitos e relaçóes concebidos como carentes de organização e controle (Souza Lima, 1995).

6. Os documentos analisados são de inteiro teor dos acórdãos, relatórios, ementas e acórdãos finais. Além disso, recorri, quando encontrei, a outros dados na internet sobre os processos para compreendê-los melhor. Alguns limites se impóem aqui, principalmente, pela forma com que tive acesso aos acórdãos, sem contato com o conteúdo dos relatórios policiais e dos recursos feitos por advogados e advogadas ou promotores e promotoras. É fato também que determinadas nuances do julgamento são perdidas, mesmo no que diz respeito às falas dos magistrados e das magistradas. Contudo, documentos possibilitam discussōes sob uma perspectiva privilegiada, pois traduzem movimentos de construção, negociação e "sedimentação" de verdades (Vianna, 2002:87). E, assim, analiso-os 
como producentes de realidade, como artefato de construção do universo simbólico institucional.

7. Para Geertz (1997:325), o direito deve ser estudado pela antropologia como um "saber local" e a ideia de sensibilidade jurídica reside sobre esse "complexo de caracterizaçóes e suposiçóes, estórias sobre ocorrências reais, apresentadas através de imagens relacionadas a princípios abstratos".

8. Como aponta Geertz (1997:254), uma vez que a representação jurídica dos fatos é normativa na modernidade, "o lugar dos fatos no universo dos julgamentos" torna-se central para sua atualizaçấo.

9. De acordo com o Código Penal, o "lugar do crime" é aquele onde ocorre a ação e onde se produziu (ou deveria ter produzido) o resultado (Brasil, 1940:art. 6º caput). A competência de processar e julgar um delito é determinada justamente a partir do lugar do crime (Brasil, 1941:art. 70, caput). Ainda, há um princípio que sujeita à lei brasileira os crimes que tocam territórios estrangeiros (na ação ou no resultado) quando são cometidos por brasileiro ou brasileira e estão previstos em tratados e convençôes ratificadas pelo país: princípio da extraterritorialidade (Brasil, 1941:art. 7º, inciso II, alíneas a e b).

10. O caso foi julgado em 2014, e o réu foi absolvido por falta de provas. O relatório do julgamento conclui que ele utilizava programas de compartilhamento, como eMule e Kazaa, para baixar conteúdos diversos, incluindo pornografia de uma forma geral; porém, não ficou constatada nenhuma evidência de que ele havia publicado materiais no site alemão nem de que baixava, armazenava ou compartilhava pornografia infantil. Esse julgamento pode ser encontrado no Diário Eletrônico da Justiça Federal da $3^{a}$ Região, edição no 95/2014, sob o número 2003.61.81.006185-7.

11. Este acórdão foi escolhido para a presente análise por ser exemplar dos relatos trazidos a mim por meus interlocutores do GECOP. Segundo eles, a partir do pedido de quebra de sigilo de dados cadastrais, a investigação da Polícia Federal na internet tem seu tempo de execução estendido e sua efetivaçáo vulnerabilizada pelo não consenso jurídico de competência (que, acredita-se no GECOP, é da justiça federal por se tratar de açôes propiciadas pelo uso da internet).

12. Esta redaçáo foi dada pela Lei $n^{\circ} 10.764$, de 2003 , que altera o texto original do artigo 241 do Estatuto da Criança e do Adolescente (ECA), que dizia: "fotografar ou publicar cena de sexo explícito ou pornográfica envolvendo criança ou adolescente" (Brasil, 1990b).

13. A ideia de "lâminas" advém do vocabulário de Goffman (1974) como conceito que abarcaria variadas dimensōes de um "enquadramento" (frame), ou seja, seriam as nuances, fragilidades e consistências de dado esquema de interpretação da realidade. Segundo o autor, a realidade é definida situacionalmente por "lâminas".

14. A ação típica, aqui, é aquela prevista no artigo 241 do ECA antes da alteração feita pela Lei 10.764, de 2003 (Brasil, 1990b). 
15. Corrupção de menores é fato típico previsto no Código Penal na redação anterior à Lei 12.015, de 2009 (Brasil, 1940:art. 218).

16. Este acórdão foi escolhido por ter sido citado em dois documentos etnográficos do GECOP. Em ambos, as citaçóes exemplificavam e justificavam a competência da justiça federal nos crimes contra a pessoa perpetrados pela internet. Para o contexto que estou abordando, esse acórdão tem uma importância específica, pois o STF é a corte máxima de resolução de conflitos de interpretação judicial: acionar suas resoluções e votos corresponde a lançar máo de argumento de autoridade que não pode ser desacreditado.

17. Nesta análise, os votos serão apresentados por blocos de discussão e não na sequência em que foram proferidos no julgamento.

18. É importante perceber que as chaves argumentativas que localizavam a transnacionalidade das açôes partindo da intenção do réu no julgamento do STJ (Brasil, 2003) foram deslocadas para outras compreensôes no STF (Brasil, 2006). No primeiro, a disciplina (Foucault, 2008a) talvez fosse um mecanismo importante de discussão no que concerne a técnicas de medição de subjetividades.

19. "O meio vai ser portanto aquilo em que se faz a circulação. [...] É esse fenômeno de circulação das causas e dos efeitos que é visado através do meio. E, enfim, o meio aparece como um campo de intervenção em que, em vez de atingir os indivíduos como um conjunto de sujeitos de direito capazes de açóes voluntárias [...], [o] que vai se procurar atingir por esse meio é precisamente o ponto em que uma série de acontecimentos, que esses indivíduos, populaçóes e grupos produzem, interfere com acontecimentos de tipo quase natural que se produzem ao redor deles" (Foucault, 2008a:28).

20. Este acórdão foi citado em documento do GECOP, um modelo de representação à justiça federal para solicitar quebra de sigilo cadastral de usuários de internet. Ele foi acionado como discurso de autoridade para legitimar a atuação da justiça federal em julgamentos de crimes de ódio e pornografia infantil na internet.

21. No sentido de Harvey (1996), simulacro entre símbolos e signos como diferentes estados de expressão da realidade.

22. Somente em abril de 2014 foi aprovado o Marco Civil Regulatório da Internet, que normatiza as ações estatais sobre a internet e seus usos (Brasil, 2014).

23. Segundo meus interlocutores, há um "consenso" e uma preocupação "mundial" a respeito do combate a práticas vinculadas ao abuso sexual infantil.

24. "Escalar", como apontam Anderson (2008) e Herzfeld (1993). Este explica que não se trata de comparaçóes de tamanho físico ou abrangência estatística, mas de imagens que permitem que as relaçóes sociais locais sejam emocionalmente locadas em territórios sociais, com um senso de coesão tal que a experiência destes se caracterizaria como um "simulacro da sociabilidade" (Herzfeld, 1993:100-101). 


\section{Referências bibliográficas}

ANDERSON, Benedict. 2008. Comunidades imaginadas: reflexóes sobre a origem e a difusão do nacionalismo. Tradução: Denise Bottman. São Paulo: Companhia das Letras. BRASIL. 1940. Decreto-Lei no 2.848, de 7 de dezembro de 1940. Código Penal. Diário Oficial da República Federativa do Brasil, Brasília, DF, 31 dez. 1940. Disponível em: http://www.planalto.gov.br/ccivil_03/decreto-lei/del2848.htm. Acesso em: 22/11/2014.

. 1941. Decreto-lei no 3.689, de 3 de outubro de 1941. Código de Processo Penal. Diário Oficial da Uniâo de 13 de out. de 1941. Disponível em: http://www. planalto.gov.br/ccivil_03/decreto-lei/del3689.htm\#art810. Acesso em: 11/04/2015.

1969. Decreto $\mathrm{n}^{\circ}$ 65.810. Promulga a Convenção Internacional sobre a Eliminação de Todas as Formas de Discriminação Racial. Disponível em: http://legis. senado.gov.br/legislacao/ListaTextoIntegral.action?id=94836. Acesso em: 22/11/2014.

1988. Constituição da República Federativa do Brasil. Brasília, DF: Senado. Disponível em: http://www.planalto.gov.br/ccivil_03/constituicao/ ConstituicaoCompilado.htm. Acesso em: 22/11/2014.

. 1990a. Decreto no 99.710. Promulga a Convençáo sobre os Direitos da Criança. Disponível em: http://www.planalto.gov.br/ccivil_03/decreto/1990-1994/D99710.htm. Acesso em: 22/11/2014.

. 1990b. Lei n. 8.069, de 13 de julho de 1990. Dispóe sobre o Estatuto da Criança e do Adolescente e dá outras providências (ECA). Disponível em: http://www. planalto.gov.br/ccivil_03/leis/L8069.htm. Acesso em: 22/11/2104.

. 2014. Lei, $\mathrm{n}^{\circ} 12.965$, de 23 de abril de 2014. Estabelece princípios, garantias, direitos e deveres para o uso da internet no Brasil. Disponível em: http://www.planalto. gov.br/ccivil_03/_ato2011-2014/2014/lei/l12965.htm. Acesso em: 22/11/2014.

BRASIL. Superior Tribunal de Justiça. 2003. Habeas Corpus no 24.858/GO. Relator: Ministro Paulo Medina. Publicado no Diário de Justiça de 06/09/2004. Disponível em: http://www.jusbrasil.com.br/jurisprudencia/19414876/habeas-corpus-hc-24858-go2002-0130648-1-stj/inteiro-teor. Acesso em: 31/03/2013.

BRASIL. Supremo Tribunal Federal. 2006. Habeas Corpus no 86.289-6. Relator: Ministro Ricardo Lewandowski. Publicado no Diário de Justiça da União em 20/10/2006, p. 62. Disponível em: www.criminal.caop.mp.pr.gov.br/arquivos. Acesso em: 11/02/2013. 
BRASIL. Tribunal Regional Federal da $3^{a}$ Regiáo, Segunda Turma. 2004. Recurso Criminal em Sentido Estrito no 48.936/SP. Relatora: Juíza Cecília Melo. Disponível em: www.criminal.caop.mp.pr.gov.br/arquivos. Acesso em: 11/02/2013.

BRASIL. Tribunal Regional Federal da $1^{\text {a }}$ Região. 2008. Recurso Criminal em Sentido Estrito no 2007.38.00.029938-5/MG. Relator: Juiz Tourinho Neto. Disponível em: http://www.nacionaldedireito.com.br/jurisprudencia. Acesso em: 11/02/2013.

FERGUSON, James \& GUPTA, Akhil. 2002. "Spatializing States: Toward an Ethnography of Neoliberal Governmentality”. American Ethnologist, 29(4):981-1002.

FOUCAULT, Michel. 2002. "A governamentalidade". In: - Microfísica do poder. Tradução e organização de Roberto Machado. Rio de Janeiro: Graal. Publicado originalmente em 1979. pp. 277-293.

. 2008a. "Aula de 11 de janeiro de 1978". In: . Segurança, território, população: curso dado no Collège de France (1977-1978). Edição estabelecida por Michel Senellart sob a direção de Francois Ewald e Alessandro Fontana; tradução de Eduardo Brandão; revisão da tradução de Claudia Berliner. São Paulo: Martins Fontes. Coleçâo Tópicos. pp. 3-38.

2008b. "Aula de 25 de janeiro de 1978". In: . Segurança, território, populaçáo: curso dado no Collège de France (1977-1978). Edição estabelecida por Michel Senellart sob a direção de Francois Ewald e Alessandro Fontana; tradução de Eduardo Brandão; revisão da tradução de Claudia Berliner. São Paulo: Martins Fontes. Coleção Tópicos. pp. 73-116.

GEERTZ, Clifford. 1997. "O saber local: fatos e leis em uma perspectiva comparativa”. In: O saber local: novos ensaios em antropologia interpretativa. Tradução de Vera Mello Joscelyne. Petrópolis, RJ: Vozes. pp. 249-356.

GOFFMAN, Erving. 1974. Frame Analysis: An Essay on the Organization of Experience. New York: Haper and Row.

GUPTA, Akhil \& FERGUSON, James. 2000. "Mais além da 'cultura': espaço, identidade e política da diferença”. In: Antonio A. Arantes (org.). Espaço da diferença. Campinas-SP: Editora da Unicamp. Publicado originalmente em 1992. pp. 30-49.

HARVEY, David. 1996. A condição pós-moderna: uma pesquisa sobre as origens da mudança cultural. São Paulo: Loyola. Publicado originalmente em 1989.

HERZFELD, Michael. 1993. The Social Production of Indifference: Exploring the Symbolic Roots of Western Bureaucracy. Chicago: The University of Chicago Press. Publicado originalmente em 1947.

JESUS, Damásio de. 2009. Direito penal - parte geral. 30a ed. São Paulo: Saraiva. v. 1. Anuário Antropológico/2014, Brasília, UnB, 2015, v. 40, n. 1: 107-131 
RABELO, Mariana Cintra. 2013. Salvar cordeiros imolados: a gestão do combate à pornografia infantil na internet e a proteção de crianças. Dissertação de Mestrado, Universidade de Brasília.

SOUZA LIMA, Antônio Carlos de. 1995. Um grande cerco de paz: poder tutelar, indianidade e formação do Estado no Brasil. Petrópolis: Vozes.

. 2002a. "Sobre gestar e gerir a desigualdade: pontos de investigação e diálogo". In: _______. (org.). Gestar e gerir: estudos para uma antropologia da administraçáo pública no Brasil. Rio de Janeiro: Relume Dumará: Núcleo de Antropologia da Política/ UFRJ. pp. 11-22.

. 2002b. "Diversidade cultural e política indigenista no Brasil". Tellus, 3(10):11-21. Disponível em: http://laced.etc.br/site/pdfs/Diversicultural.pdf. Acesso em: 25/03/2013.

VIANNA, Adriana de Resende Barreto. 2002. Limites da menoridade: tutela, família e autoridade em julgamento. Tese de doutorado, Museu Nacional da Universidade Federal do Rio de Janeiro. 


\section{Resumo}

Este artigo analisa a centralidade que a definição de territórios assume em conflitos de competência judicial em casos de crimes contra pessoas perpetrados através da internet. A discussão recai sobre um contexto produtivo de enquadramentos de imaginação e autoridade jurídica. Como podem ser territorializadas açôes ilícitas perpetradas pela internet? Como, nesses casos, se atualiza a aplicação do direito penal? Com base no estudo de acórdãos, é possível apreender processos de negociação e transformação das sensibilidades de espaço-tempo acerca da experiência da e na internet. Procuro mostrar que a construção da internet como território juridicamente gerível e, neste contexto, de feiçôes transnacionais ou com potencialidade internacional é um empreendimento de gestão recente, datado principalmente dos anos 2000, e não absoluto.

Palavras-chave: internet; direitos humanos; competência judicial; território; transnacionalidade.
This paper analyses the juridical interpretations of conducts performed on the internet, focusing on the central role that the definition of territories assumes on the legal-penal treatment of illicit activities against people. The objective is to discuss how the juridical practice can produce frameworks related to territories and territorial experiences. How can the virtual illicit actions in territorial terms be constructed? How is the criminal law usage updated in these cases? It is possible to recognize, on the judicial speeches, how they trigger and recreate sensibility regarding the space and time of internet usage. The discussion focuses on recent and relative processes that build the internet as a transnational territory or as an international potential environment.

Keywords: internet; human rights; jurisdiction; territory; transnationality. 